\title{
DNM2 Gene
}

National Cancer Institute

\section{Source}

National Cancer Institute. DNM2 Gene. NCI Thesaurus. Code C102796.

This gene plays a role in both GTP hydrolysis and microtubule organization. 